\title{
THE INFLUENCE OF LEADERSHIP, WORK MOTIVATION AND COMPENSATION ON THE PERFORMANCE OF EMPLOYEES OF PT. JAVA-BALI PLANTATION HEAD OFFICE IN SURABAYA
}

\author{
${ }^{1}$ Rismawati Sitepu ${ }^{2}$ Ilham ${ }^{3}$ Martin Zebua ${ }^{4}$ Emmywati, ${ }^{5}$ Noneng R S, ${ }^{5}$ Bambang Sri Wibowo \\ rismawati.sitepu@stiemahardhika.ac.id
}

\begin{abstract}
This study aims to examine and determine the relationship between leadership, motivation, and compensation for employee performance at PT. Generation of Java-Bali Headquarters in Surabaya. With the results of the study as follows: 1. Based on the data in the table above, the calculated $t$ value of 3,876. Because the value of $t$ count $<t$ table (1.66023> 3.876) and the probability value of significance $(0.00<0.05)$ then $\mathrm{HO}$ is rejected and $\mathrm{Ha}$ is accepted. This means that leadership partially has a significant effect on the performance of PT. Surabaya Java-Bali generation. 2. Based on the t table of 0.291. So that t count <t table $(1.66023<4.976)$ and the value of the probability of significance $(0.00<0.05)$ then $\mathrm{Ho}$ is rejected and $\mathrm{Ha}$ is accepted. This means that work motivation partially has a significant effect on the performance of PT. Surabaya Java-Bali generation. 3. Based on t table of 0.291 So that $t$ arithmetic $<t$ table $(1.66023<2.972)$ and the probability value of significance $(0.00<0.05)$ then Ho is rejected and Ha is accepted. This means that partial compensation has a significant effect on the performance of PT. Surabaya Java-Bali generation. 4.Based on the $f$ table of 2.81. B ecause the value of $f$ arithmetic> $f$ table (35,669> 2.81) then $\mathrm{Ho}$ is rejected and Ha is accepted, which means. L eadership, work motivation, and compensation simultaneously have a significant effect on the performance of the employees of PT. Surabaya Java-Bali generation.
\end{abstract}

\section{Keywords: Leadership, Motivation, Compensation, and Performance}

\section{PRELIMINARY}

Work is basically an effort that is carried out continuously to obtain a set of knowledge and skills with the help of other people to obtain optimal results. In order to gain a competitive advantage in facing competition, every organization and individual must prepare themselves professionally. Reliable human resources are a requirement absolutely support the success of an organization.

To achieve organizational success, the leadership must respond quickly to any changes and challenges that occur. In organizations, one form of response that must be taken by the organization is to prepare reliable human resources by creating a good organizational culture, providing work motivation, and increasing the work ability of employees to achieve work performance.

The leader is a person who has the skills and strengths, in particular skills / excess in one area so that he is able to mempengruhi others to jointly carry out certain activities for the achievement of one or be some a destination (Kartini Kartono, 2015:181 ). A leader can not b erdiri itself or act as if he were the sole perpetrators of an organization. A dreamer $n$ act to bring all the 
components of the organization to move towards the goal. Thus it can be said that a leader is chosen because he has various abilities, techniques, and leadership styles that influence his subordinates in order to achieve the goals and objectives set.

The challenges in the era of globalization and free trade which make business competition even tighter have placed the quality and competence aspects of human resources very important, especially to be able to answer the challenges and opportunities that exist. The quality of human resources does not only fill roles created by the impact of the demands of the times, but the quality is more directed to encourage the creation of new ideas in dealing with these changes. Improving the quality of human resources has been carried out through the development of quality improvements and education quality. Not only in the world of education, but also in companies - companies also create creative human resources who are able to generate new ideas and new ways in order to survive, even thrive in the competitive world.

In overcoming the low quality of performance, the leader should know that the disturbance of his positive leadership techniques is a more effective approach to his subordinates. Leaders who think positively are a more effective approach to their subordinates. Positive-thinking leaders will assume that most people want to do a good job, if their efforts are appreciated by the leadership. The leader must be able to explain why a job must be done and not force his subordinates to do it, so that the employees under him can do it well. But in reality, there are still ineffectiveness in achieving goals.

An effective employee performance appraisal system in the context of developing the quality of human resources basically must meet the following requirements: relevant, senisitivity, reliability, and consistent, namely obeying objective, open, fair, and accurate principles so as to create a motivating feedback process. employees to improve their performance. For employees, education and training are means to assist organizations in improving employee performance. The results of the performance appraisal are expected to motivate employees to improve their performance to be better and to continuously make improvements to their performance simultaneously. If every employee of the company can improve his career, an employee must really think and plan his career development well because good planning is half of a success.

Efforts to improve the quality of human resources, especially the company's human resources, need to be done well, directed and planned, so that companies can compete fairly with other companies. Given that in the future the competition between companies will be tougher. Only companies that have quality human resources can compete with competitors or business partners. Quality resources can only be obtained through planned and targeted planning and coaching, which are able to read the trends of the labor market at any time and be able to appropriately adjust to the needs of society.

Hasibuan $(2015: 224)$ states that human resources are the first and foremost element in every activity carried out. Reliable or sophisticated equipment without the active role of human resources does not mean anything. Together with the leadership issue for human history a, in kepemimpina $n$ people need for their specific limitations and advantages in humans. Whether people in society or an organization cannot carry out their duties and functions without a leader, there are at least four reasons, namely : because many need a leader figure, in some situations a leader needs to appear to represent his group, as a place to take risk if it occurs pressure on the group, and as a place to put power. 


\section{THEORETICAL BASIS}

According to Build cited by Sutrisno (2014: 6) "Human Resources department " human being is a process of organization, mobilization, planning, development, compensation administration, integration, maintenance and the division of labor to achieve organizational goals". Meanwhile, according to Schuler, quoted by Sutrisno (2014: 6), defines human resource management (HRM), "is an acknowledgment of the importance of organizational workforce as a very important human resource in contributing to organizational goals and using several functions and activities to ensure that human resources (HR) are used effectively and fairly for the benefit of individuals, organizations and communities. Human resource management has a duty to manage the human element properly in order to obtain a workforce who is satisfied with their work.

Menur ut Siagian in Riandji (2017: 86), kepemipinan/lead is different from the leader. Leadership / leadership is seen as a process of influencing group activities organized in an effort to determine goals and achievements. Whereas a leader is someone who has the task of directing and guiding his subordinates and is able to obtain support from his subordinates so that they can move them (subordinates) towards achieving organizational goals. In other words, the leader is the person who takes the lead. Leadership ability, namely the ability of managers to motivate, influence, direct, and communicate with subordinates. A person who has a leadership position in an organization has the task of carrying out leadership. The leader is the person and leadership ( leadership ) is activity.

According to Gibson et al. in Riandj i (2017:20), leadership is a narrower concept than management, even though managers as management actors in carrying out functions such as planning, organizing and controlling play a role as a leader. However, there are also leaders in informal groups. Informal leaders are not always formal managers who carry out the management functions required by the organization. The leader is only sometimes the real manager. Leader and leadership are behaviors that show the ability of the leader, while leadership is the quality of the abilities and personalities the leader has to move his followers.

Leadership comes from the word leadership, which is an adjective that a leader has, while a leader is a person who leads. Leadership has a close relationship with a group of people who have the same goals, while these goals have been previously determined in one organization.

In organizational life, sharing perauran, procedures, work mechanism and the like are not intended untuk obviate kep emimpinan in the organization. It -things ter s ebut precisely auxiliaries for the leadership of his leadership run effectively. There are several meanings of leadership that are adopted from the book thoha (2013:3). George R. Terry expressed the notion of leadership as "leadership in one person, or the leader, other influences work together willingly or realeted task to attain that wich the leader desire". Which means leadership is a relationship that exists within the leader, influencing others to work consciously in a relationship of duty to achieve what they want. James AF Stoner expressed the notion of leadership as "managerial leadership as a process of directing and influencing the ask related activities of group members".

Which means managerial leadership as a process of directing and influencing the activities of group task relations. Paul Hersey and Kenneth $\mathrm{H}$. Blanchard put forward the notion of leadership as "leadership is the process of influencing the activities of an individual or group in effort to word goal achievement in a given situation". Which means leadership is the process of influencing individual or group activities in an effort to achieve goals in certain situations. 
Motiva for work, according to Danang (2012: 191), motivation is a stimulant for a person's desire to work, each motive has a specific goal to be achieved. According to Handoko (2003: 74) motivation is a state in the person of someone who encourages the desire of individuals to conduct - certain activities to achieve the goal. Motivation is an indicator that makes a worker more satisfied in carrying out his activities. Work motivation can be a driving force in humans and can direct their behavior to carry out their duties and responsibilities (Panggalih \& Zulaicha, 2012).

Motivation is always the main concern of managers, because motivation is closely related to the success of a person, organization or society in achieving its goals. According to Hasibuan (2010: 92) reveals that motivation is very important because with motivation it is hoped that each individual can generate the desire to work hard to achieve high work productivity .

According to Wibowo (2014: 323) Motivation is the encouragement of a series of processes of human behavior in achieving goals. While the elements contained in motivation include elements of arousing, directing, maintaining, showing intent, being continuous and having a purpose. Motivation has two basic forms, namely artificial (extrinsic) and intrinsic (intrinsic ), in employee performance.

Compensation is an expense and expense for the company. The company expects that the reward paid gets a work performance reward that is greater than the reward paid.

Hasibuan in Hadi states $(2017$ : 118) compensation is all income in the form of money, direct or indirect goods received by employees as compensation for services provided to the company.

According to Hasibuan in Hadi ( 2017 : 18) compensation is divided into two, namely: direct compensation in the form of salaries, wages and incentive wages and indirect compensation or indirect compensation for employee welfore or employee welfare. Salary is remuneration that is paid periodically to permanent employees and has a definite guarantee. That is, the salary is still paid even if the worker does not come to work.

Generally there is no differentiation between the definition of performance, work performance or work results, so that in providing the concept of performance, work performance or work results, experts often use it as they wish without any distinction. For this reason, in this paper the concept of performance, work performance or work results is not differentiated and can be used interchangeably by providing the same definition. Sedarmayanti (2013; 27 ) defines performance as performance, work performance, work implementation, work achievement or work results / for work / work performance. Dharma (2013; 45 ) states that work performance is something that is done or a product / service is produced or given by a person or group of people. Likewise , Gibson et al $(2013 ; 106)$ states that work performance is the desired result of behavior in which individual behavior in work organizations is different, therefore their performance will be different as well for a work team.

Flippo $(2013 ; 286)$ states that in order to achieve high performance, it depends on cooperation, personality, diverse intelligence, leadership, safety, work knowledge, attendance, compensation, toughness and initiative. Cooperation means togetherness between employees in the organization in order to carry out their duties and jobs, which work together between superiors and subordinates as well as cooperation between subordinates. The personality of the employee greatly determines the good and bad results of the work. Employees who have a good personality will certainly have optimal performance. Intelligence will make an employee fast and precise in doing their duties and jobs. Intelligence comes from education as well as from 
experience. Likewise leadership, leadership that accommodates subordinates will be more conducive to achieving the goals of an organization. Initiatives employees to complete tasks and work is also greatly affect the work, the higher the power of initiative in Completion of the task and his work, then the work can also be said that the performance of employees affected by the cooperation, personality, intelligence diverse $\mathrm{r}$ a gam, kepemimpina $\mathrm{n}$, safety, job knowledge, attendance, compensation, resilience and initiative.

Robbin $(2013 ; 29)$ states that employee performance is a function of the interaction between motivational abilities, if something is inadequate, that performance will be negatively affected. Intelligence and skills (which are classified under the label ability) must be considered in addition to motivation. However, in Robbins' theory, the opportunity to perform is also added, which is defined as high levels of performance, in part, as a function of the absence of obstacles that keep an employee in check. The obstacles that hinder performance are in the form of a work environment that is not supportive, equipment, materials, inadequate supply, colleagues, and procedures that are less supportive. So according to Robbins, employee performance is influenced by ability, motivation and opportunity, and ability.

Of beber a pa earlier suggestions, it was concluded that the performance or work performance is the result of work achieved by someone to perform a task based on the size that applies to the task assigned to him in accordance with the criteria d itetapkan within a certain time.

\section{CONCEPTUAL FRAMEWORK}

This study will look for the influence of leadership, work motivation, and compensation on the performance of employees of PT. Generation Java-Bali Head Office in Surabaya . For this purpose, the conceptual framework of research is shown in the following figure :

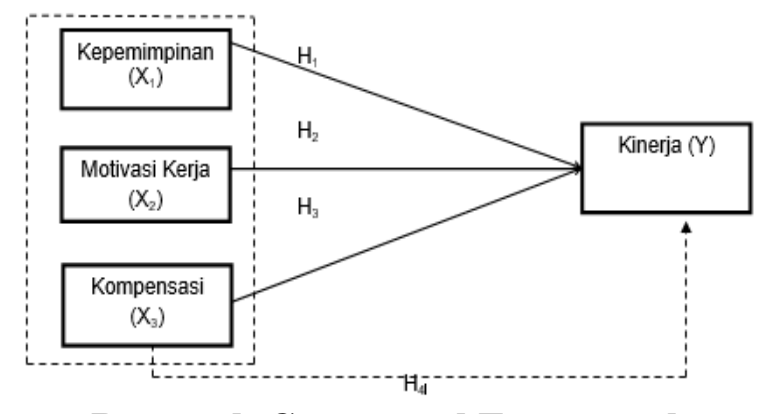

Research Conceptual Framework

\section{Remarks :}

\section{: Parsial}

: Simultan

\section{RESEARCH HYPOTHESIS}

The hypothesis of this study is based on the description of the problem formulation as follows:

a. That leadership $\left(\mathrm{X}_{1}\right)$ partially affects the performance of employees (Y) PT. Java - Bali generation .

b. That work motivation $\left(\mathrm{X}_{2}\right)$ has a partial effect on employee performance (Y) PT. Java - Bali generation . 
c. Whereas Compensation $\left(\mathrm{X}_{3}\right)$ has a partial effect on employee performance (Y) PT. Java Bali generation .

d. That Leadership $\left(\mathrm{X}_{1}\right)$, Work Motivation $\left(\mathrm{X}_{2}\right)$, and Compensation $\left(\mathrm{X}_{3}\right)$ have a simultaneous effect on employee performance (Y) PT. Java - Bali generation .

e. That Work Motivation $\left(\mathrm{X}_{2}\right)$ is the most dominant influence on employee performance (Y) PT. Java - Bali generation .

\section{RESEARCH METHODS}

This type of research is explanatory research because it aims to test the formulation of problems that have been previously formulated. are compiled based on previous research and scientific experiences. This research is limited to the importance of leadership, work motivation and compensation in increasing the productivity of the employees' performance at PT. Generation Java-Bali Head Office in Surabaya. In the variable is three vari abel free, ie Leadership, Motivation, and variable compensation while smoking is employee performance (Y). The subject of this research focuses on the employees of PT. Generation JavaBali Head Office in Surabaya .

Beni Ahmad (2013: 105 ) states that data processing is analyzing data with certain methods and methods that apply in research. To support the achievement of the objectives of the problem in this study, two types of data sources will be used, namely primary data and secondary data. The following is a description of the two types of data sources:

1. Primary data

The data collected directly by the researcher from the research object. Primary data is data obtained and collected directly from the research location through a list of questions / questionnaires given to all BBH Surabaya employees who are assigned as samples.

2. Secondary Data

This data was obtained from other parties and collected by researchers. Thus, when the research was conducted, the data already existed. Secondary data in this study is data obtained from employees of PT Pembangkitan Jawa - Bali, including regarding organizational structure, job descriptions, relevant literature sources, magazines and research.

Data collection techniques are related to the mechanisms that must be used by researchers in collecting data. Without knowing the data collection techniques and mechanisms, researchers will not get data that meets the established data standards.

Data collection can be done in a variety of techniques, sources and ways. According to Beni Ahamd (2013: 81 ) in terms of technique, it can be collected in natural techniques. Labotarium with experimental methods, a house with various respondents, seminars, discussions, and others. Judging from the data source, data collection can use primary and secondary sources. As seen in terms of data collection methods and mechanisms, data collection techniques can be carried out by means of observation, interview, questionnaire, documentation, and a combination of the four.

\section{a. Leadership $\left(\mathbf{X}_{1}\right)$}

\section{RESULTS AND DISCUSSION}

To find out the value of $t$ table, use $t$ table with a significant level a with a value of $5 \%$, using a two-way test and degrees of freedom, namely $\mathrm{n}-\mathrm{k}(100-4=96)$. Then the $\mathrm{t}$ table is obtained for 1.66023 . Based on the data in the table above, the $t$ value is 3,876 . Because the 
value of $\mathrm{t}<\mathrm{t}$ table $(1.66023>3,876)$ and the probability of significance $(0.05<0.00) \mathrm{H} 0$ is rejected and $\mathrm{Ha}$ accepted. That is leadership partially significant effect terh a dap performance of PT. Surabaya Java-Bali generation .

\section{b. Work Motivation $\left(\mathbf{X}_{2}\right)$}

Based on the table above, obtained t count of 4.976 with a significance level of a with a value of 5\%, and using a two-way test and degrees of freedom, namely $\mathrm{n}-\mathrm{k}(100-4=96)$, the $\mathrm{t}$ table is 0.291 . So that $\mathrm{t}<\mathrm{t}$ table $(1.66023<4,976)$ and the probability of significance $(0.05<\mathrm{a} 0,00)$, then $\mathrm{Ho}$ is rejected and $\mathrm{Ha}$ accepted. This means that partially work motivation has a significant effect on the performance of PT. Surabaya Java-Bali generation .

\section{c. Compensation $\left(\mathbf{X}_{3}\right)$}

Based on the table above, it is obtained t count of 2,972 with a significance level of a with a value of 5\%, and using a two-way test and degrees of freedom, namely $\mathrm{n}-\mathrm{k}(100-4=96)$, the obtained t table is 0.291 so that $\mathrm{t}<\mathrm{t}$ table $(1.66023<2,972)$ and the probability of significance ( $0.05<\mathrm{a} 0.04$ ), then Ho is rejected and Ha accepted. This means that partial compensation has a significant effect on the performance of PT. Surabaya Java-Bali generation .

Because all variab e 1 beb as having a significant effect, it can be ascertained that the hypothesis can first be accepted. Namely "take hleadership, motivation, and compensation partially significant effect on the performance of employees of PT. The JavaBali Surabaya Generation . " D apat accepted.

\section{ANOVA ${ }^{b}$}

\begin{tabular}{|c|c|c|c|c|c|c|c|}
\hline Model & \multicolumn{2}{|c|}{ Sum of Squares } & Df & $\begin{array}{l}\text { Mean } \\
\text { Square }\end{array}$ & $\mathrm{F}$ & \multicolumn{2}{|c|}{ Sig. } \\
\hline \multirow[t]{3}{*}{1} & ession & 181,326 & 3 & 60,442 & & & 000 \\
\hline & dual & 162,674 & 96 & 1,695 & & & \\
\hline & & 344,000 & 99 & & & & \\
\hline
\end{tabular}

a. Predictors: (Constant), Leadership, Work Motivation, Compensation

\section{b. Dependent Variable: Performance}

The table above, shows f count of 35,669 with a significant level of $0.00 \mathrm{a}$ while the $\mathrm{f}$ table with the formula:

Determines the degree of freedom $(\mathrm{df})$

Table f, there are two (df) namely df (n1) and df (n2)

Formula :

Df $(\mathrm{n} 1)=\mathrm{k}-1=4-1=3$

Df $(\mathrm{n} 2)=\mathrm{n}-\mathrm{k}=100-4=96$

So, the $f$ table is 2.81 . because the value of $f$ count $>f$ table $(35,669>2.81)$ then Ho is rejected and $\mathrm{Ha}$ is accepted which means. leadership, motivation, and compensation are simultaneously significant effect on the performance of employees of PT. Surabaya Java-Bali generation. So that the second hypothesis which states "that the leadership, motivation, and compensation are simultaneously significant effect on the performance of employees of PT. Generation Java-Bali Head Office in Surabaya Acceptable. 
To find variab e 1 which domi nan influence among variab e 1 freely viewable from standardized regression coefficient rankings standardized of beta coefficient of each -masing free variable. The independent variable which has the dominant influence on the dependent variable.

Based on the statistical data in the table above, it is known that the free variable that has the largest beta coefficient is the Work Motivation variable $\left(\mathrm{X}_{2}\right)$ with a standard beta coefficient value of 0.388 . Thus it can be concluded that the third hypothesis is accepted, namely the variable work motivation has a significant and most dominant effect on the performance of employees of PT. Surabaya Java-Bali generation .

Based on the results of the regression coefficient above, leadership partially has a significant positive effect on the performance of the employees of PT. Generation Java-Bali Head Office in Surabaya. Which means that if leadership increases will affect the performance of employees of PT. Generation Java-Bali Head Office in Surabaya. This statement is supported based on the theory of Hasibuan in Riandji (2017) which states that leadership is an effort to influence people to participate in achieving common goals. Handoko in Riandji (2017) states that leadership is an interpersonal influence that is carried out in situations and is directed, through a communication process, towards the achievement of certain goals or objectives. Meanwhile, Swasto in Riandji (2017) defines leadership as it relates to the process of influencing individual or group activities in an effort to achieve goals in certain situations. Which means that leadership is related to an individual or group activity process.

1. Based on the results of the regression coefficient above, partially work motivation has a positive significant effect on the employee performance of PT. Generation Java-Bali Head Office in Surabaya. Which means if increased work motivation will affect the performance of employees of PT. Generation Java-Bali Head Office in Surabaya. This statement is supported based on the theory according to Wibowo (2015, P. 323) Motivation is the impetus for a series of processes of human behavior in achieving goals. While the elements contained in motivation include elements of arousing, directing, maintaining, showing intensity, being continuous and having a purpose. Motivation has two basic forms, namely artificial (extrinsic) and intrinsic (intrinsic), in employee performance. companies need both to help increase employee performance (extrinsic and intrinsic), e-xtrinsic is about what the company will do to motivate employees, while intrinsic is the factors or causes from within the company to motivate employees with specific goals . Because every employee must have the motivation why they work at the company they choose. Which means that this motivation relates to individual behavior to encourage it to process in an action.

2. Based on the results of the regression coefficient above, partially compensation has a significant positive effect on the performance of the employees of PT. Generation Java-Bali Head Office in Surabaya. Which means that if the increased compensation will affect the performance of employees of PT. Generation Java-Bali Head Office in Surabaya . This statement is supported based on theory According to Werther and Davis in Wibowo ( 2016 : 134 ) defines compensation as what workers receive in exchange or their contribution to the organization. In compensation there is an intensive system that links compensation to performance. Compensation for workers is awarded based on performance and not based on seniority or number of hours worked. Which means that compensation is related to performance, because compensation is a form of reciprocity and company appreciation of employees 
3. Based on the results of the regression coefficient above, simultaneously leadership, work motivation, and compensation have a significant positive effect on employee performance at PT. Generation Java-Bali Head Office in Surabaya . Which means that if leadership, work motivation, and compensation increase simultaneously will affect the performance of employees of PT. Generation Java-Bali Head Office in Surabaya . This statement is supported based on the theory of Siagian (2015) which states that high quality work will in turn give rise to rewards and progress not only in achieving personal goals and the members of the organization concerned. Accurate identification of the causes of one's performance is fundamental to good supervision and more effective decision-making in performance improvement strategies. The factors that affect performance can come from internal and external. From internal sources are capabilities and efforts while from external sources such as low assignments, good luck or good economy or because of that one of the main elements that need to be considered for improving employee performance is leadership support.

4. Based on the results of the regression coefficient above, the work motivation variable has the highest beta value among other independent variables. Which means that work motivation is the variable with the most dominant level of influence on the performance of the employees of PT. Generation Java-Bali Head Office in Surabaya .

\section{CONCLUSION}

1. In the results of the analysis and discussion in this study states that leadership has a partially significant effect on the performance of employees of PT. Generation Java-Bali Head Office in Surabaya. Therefore, leadership is a relationship that exists within the leader, influencing others to work in a conscious manner in a relationship of duty to achieve what the company wants.

2. In the results of the analysis and discussion in this study states that work motivation partially significant effect on the performance of employees of PT. Generation Java-Bali Head Office in Surabaya. Therefore motivation is always the main concern of managers or company leaders because motivation is closely related to the success of a person, organization or society in achieving its goals.

3. In the results of the analysis and discussion in this study states that compensation has a partially significant effect on the performance of employees of PT. Generation Java-Bali Head Office in Surabaya. Therefore compensation is something that is considered as an equivalent. In employment, gifts in the form of money are compensation given to employees as a reward for their service.

4. In the results of the analysis and discussion in this study states that leadership, work motivation, and compensation simultaneously have a significant effect on the performance of employees of PT. Generation Java-Bali Head Office in Surabaya. Therefore working productively or not, depending on motivation, leadership , compensation system, job design, technical economic aspects and other behaviors. Every nation memilii different cultures that men gakibatkan differences in behavior ( behavior) and attitude (attitute) in the activities of the organization. Differences in behavior due to culture and geographic environment will result in differences in job performance .

5. That work motivation is the most dominant influence on the performance of employees of PT. Generation Java-Bali Head Office in Surabaya. Therefore the role of leadership in 
Journal of Islamic Economics Perspectives, Volume 3. Issue 2 (2021)

providing motivation in the company is very important to encourage increased employee performance.

\section{REFERENCES}

Arikunto, Suharismi. 2010. Research Procedures: A Practice Approach (Revised Edition). Jakarta: PT. Rineka Cipta.

Dessler, Gary. 2005. Human Resource Management. Jakarta: PT. Index.

Dharma, Agus. 2003. Work Performance Management.

Dharma „Hendrawan. 2006. Performance Management To Create Competitive Advantage Yogyakarta: Graha Science.

Filipo , Henry. 2006. Human Resource Management. Yogyakarta: STIE YKPN.

Ghozali, Imam. 2011. Multivariate Analysis Application with SPSS Program. Third Edition. Diponegoro University Publishing Agency. Semarang.

Gibson, et.al. 2006. Organization (Translation). Fifth Edition, Jakarta: Erlangga Ghozali, 2006. Nonparametric statistics, Semarang: UNDIP Publishing Agency

Ha ndoko, Marihot Tua Efendi. 2009. Human Resource Management. Jakarta: Grasindo.

Ha Dede. 2002. Managerial Ability in Motivating and Disciplining Employees is associated with Work Productivity. Bandung: UPI PPs. Unpublished thesis.

Hasibuan, Malayu, SP 2007. Organization and Motivation . Jakarta: Earth Literacy. Jakarta: CV. Eagle.

Mangkunegara, AA Anwar Prabu. 2000 . Company Human Resource Management . Bandung: Youth Rosda Karya.

Nitisemito, Alex S. 2002. Personnel Management Revised Edition. Jakarta: Ghalia

Rivai, 2005. Performance Appraisal: The Right System To Assess Employee Performance and Improve Company Competitiveness. Jakarta: PT Rajagrafindo Persada

Ruky, SA, 2006. Performance Management Systems. PT. Bumi Aksara, Jakarta.

Siagian, 2003. Organizational Behavior. Volume 1. Translated Index Team. Jakarta: PT Gramedia Group Index.

Simora, Stephen, P. 2002. Principles of Organizational Behavior. Edition: Fifth. Translated by Halida Dewi Sartika. Jakarta: Erlangga 
Journal of Islamic Economics Perspectives, Volume 3. Issue 2 (2021)

Sedyamati , 2007. Tips for Improving Performance, First Edition. PT. Rineka Cipta; Jakarta.

Sugiyono. 2009. Statistics for Research, Alfabeta, Bandung.

Sugiyono. 2008. Business Research Methods . Bandung: Alfabeta.

Suharyadi and Purwanto, SK 2004. Basic Statistics. Jakarta: Four Salemba. 